DOI: $10.15503 /$ jecs20162.355.363

\title{
THE TRENDS IN ANTI-SEMITISM IN THE CZECH REPUBLIC 2004-2014
}

\author{
EVA TATEROVÁ
}

Faculty of Regional Development and International Studies, Mendel University in Brno, Zemedelska 4, 61300 Brno, Czech Republic

E-mail address: eva.taterova@mendelu.cz

MARCELA URBANÍKOVÁ

Faculty of Regional Development and International Studies, Mendel University in Brno, Zemedelska 4, 61300 Brno, Czech Republic

E-mail address: 45097@node.mendelu.cz

\begin{abstract}
This paper aims to introduce the current trends in anti-Semitism in the Czech Republic in 2004-2014. This period maps the changes that appeared since the end of Second Palestinian intifada to the year 2014 which is the last year with available set of data of anti-Semitism in Czech society. The article shall examine whether there is a direct link between the contemporary important events in the Middle East and the changing number of anti-Semitic incidents in the Czech Republic. The attention shall also be given to the issue which groups of Czech society are mostly associated with anti-Semitism and what is their main motivation to participate in the anti-Semitic campaign.
\end{abstract}

Key words: anti-Semitism, Czech Republic, Israel, Jews, radicalism

\section{INTRODUCTION}

The phenomenon of anti-Semitism has existed for more than two thousand years. The very first expressions of antisemitism can be found in antiquity. They were based on xenophobia and ethnocentrism. The anti-Jewish attitudes resulted from the incompatibility and conflict between Jewish and Greco-Roman doctrines. In the past, the causes of the hatred for Jews were primarily the different religious and cultural traditions. With the development of modern society and a progressive secularization the prejudices against Jews had transformed on to a completely different level. The new dimensions of antisemitism included especially the ethnic and national basis. After the tragedy of the holocaust, it would have seemed that antisemitism had no place in a modern society anymore. Despite this presumption, more than 
70 years after the end of W.W. II the hatred for Jews has never disappeared completely (Messadié, 2000). The Czech Republic is no exception as there are the anti-Semitic incidents every year.

The aim of this paper is to introduce the contemporary trends related to anti-Semitism in the Czech Republic in years 2004-2014. The research is based on the data available in the annual reports on antisemitism in the Czech Republic issued by the Jewish Community in Prague. Anti-Semitism in the Czech Republic today is mainly associated with the marginal groups in the society, especially with the extreme right-wing and the extreme left-wing organizations. The article will analyse the sources of antisemitism in the Czech Republic, and the evolution of trends in antisemitism in the Czech Republic in the given period 2004-2014.

\section{THE JEWISH MINORITY IN THE CZECH TERRITORY}

The history of the Jews living in the territory of today's Czech Republic is long and eventful. According to the historical records, the first Jews have settled on Czech territory in the 10th century AD. Similarly as in other European countries their rights were restricted in many ways, and Jews had to face up to the various types of repression in their everyday lives. They obtained the full citizen status in 1848 due to the constitutional changes but the antisemitism in the society was still quite obvious. The legal and social status of Jews in the so called first Czechoslovak republic (1918-1938) can be described as the best in previous history. Jews were not only tolerated, they were even allowed to present their Jewish nationality officially (Frankl, \& Jensovska, 2013, p. 146 - 151). On the political level, they were represented by the Jewish Party (in original: Židovská strana). Obviously, the situation changed dramatically after the breakup of Czechoslovakia in 1938, respectively in March 1939 when the remaining part of Czechoslovakia went under the direct rule of Nazi Germany as the Protectorate of Bohemia and Moravia. Since then, Czech Jews became the subject to the racist law inspired by the famous Nuremberg Law issued in 1935. Deportations of Czech Jews to Theresienstadt concentration camp, and later to the extermination camps in Germany and Poland were launched in autumn 1941. There are no exact numbers, but it is believed that more than 75.000 Czech Jews died during Holocaust (Krejčová, Svobodová, \& Hyndráková, 1995, pp. 581-582).

After the end of WW2 the tragedy of the Holocaust was recognized internationally but the phenomenon of antisemitism has not disappeared up till today. As for Czechoslovakia, the status of Jews was affected by the communist coup in February 1948. While in the early years of communist rule, there was a close cooperation between Czechoslovakia and Zionist movement/ State of Israel ${ }^{1}$, in the early 1950s the mutual relations turned in reverse. The growing hostility of the Czechoslovak government towards Israel and Jews

1 Declared on 14th May 1948 in Tel Aviv. 
living in Czechoslovakia escalated in the time of the show trials with Rudolf Slánský, the former General Secretary of the Communist Party of Czechoslovakia, and 14 of his co-workers. As Slanský himself and 11 out of 14 defendants were of Jewish origin, the anti-Semitic proclamations became an integral part of the political processes in 1950s (Ströbinger, 1991; Kaplan, 1992). As a result, the diplomatic relations between Czechoslovakia and Israel after 1953 can be described as very cold and hostile. In response to the events of the Six Day War in 1967 Czechoslovak diplomacy decided to break the official diplomatic relations with Israel.

For the rest of the Cold War, the status of Jews in Czechoslovakia was rather difficult as they were perceived as a fifth column and in general, a suspicious element. Therefore they were monitored by Czechoslovak secret service constantly (Zídek, \& Sieber, 2009, p. 143). After the events of the Velvet Revolution in 1989 that led to the transition to democracy in Czechoslovakia, both the status of Czechoslovak Jews and the diplomatic relations between Czechoslovakia/Czech Republic and Israel changed significantly. Following the change of the political regime in Czechoslovakia, several laws that condemn discrimination and any kind of attacks against members of any racial, ethnic, religious or class groups have been adopted. However, despite the existing law anti-Semitic incidents appear in the Czech society regularly.

Currently, there is a population of approximately 3.900 Jews living in the Czech Republic according to the American Jewish Year Book (The Virtual Jewish Library, 2014). The data by Czech Statistical Office from the last census in 2011 state a number 1.132 Czech Jews (Český statistický úřad, 2011). The estimates of the Federation of the Jewish Communities say that there are about 15.000 to 20.000 people of Jewish origin (FŽO, 2010). To provide the exact numbers of Jewish population in the Czech Republic is quite problematic due to the discrepancies in terms who is a Jew, and who is not. The issue is complicated by the fact that Jewishness consists of various aspects such as ethnicity, religion, culture, nationhood, and common history. Therefore there are many differences in definitions, and also in methodology of the data collection. E. g. there is one definition according to the Israeli immigration law (Law of Return): "Jew means a person who was born of a Jewish mother or has become converted to Judaism and who is not a member of another religion" (Israel Ministry of Foreign Affairs, 2013). Later in 1970, there was an amendment to Law of Return stating "[...] as well as the rights of an oleh under any other enactment, are also vested in a child and a grandchild of a Jew, the spouse of a Jew, the spouse of a child of a Jew and the spouse of a grandchild of a Jew" (Israel Ministry of Foreign Affairs, 2013).

The Law of Return, however, is sometimes criticized by Jewish religious authorities that insist on the strict implementation of religious law (Halakha). As for data issued by Czech Statistical Office, the category "religion" in the census is voluntary for the respondents so we can expect that for various reasons not all Jews living in the Czech Republic are willing to confess their religion. In any case, we can assume that the Jewish population in the Czech 
Republic counts up to thousands. It is a minority in a nation of more than 10 million but concurrently, it is numerous enough to be a potential target of anti-Semitic motivated hatred. When the phenomenon of anti-Semitism in a particular country is analysed, it is necessary to consider not only the internal political and social circumstances, but also the current situation in the Middle East. In general, we can observe the dependence between the political crises in Arab-Israeli conflict, and the rise of anti-Semitism abroad.

\section{CONTEMPORARY TRENDS IN ANTI-SEMITISM IN THE CZECH REPUBLIC}

Anti-Semitism that can be defined as the hatred or the prejudice against the members of the Jewish nation has a long tradition in Europe. Thanks to the philosophy of the Enlightenment and the emphasis on rationality and reason in the 18th century we can observe the increase of tolerance towards Jews. Yet, some prejudices, suspicion and in the worst case a direct hatred against the Jewish people has endured in most European countries, including the Czech Republic (Danics, \& Kamín, 2005, p. 131). The causes of anti-Semitism are numerous. Traditionally, we can observe the following four types of anti-Semitism in Czech society: Christian, secular, based on biologically oriented theories, and anti-Semitic attitudes based on economic reasons. Following the declaration of the State of Israel in 1948 an entirely new type of anti-Semitism appeared. In this perspective, a criticism of Israel becomes the encrypted manifestation of hatred against the Jewish community worldwide (Čeněk, Smolík, \& Vykoukalová, 2016, p. 232-235).

Christian anti-Semitism works with on the belief that Judaism as a religion was overcome by Christianity. Concurrently, the Jews are often blamed for the death of Jesus Christ (Mikulášek, 2000, p. 15). A second type is a secular anti-Semitism that denies all religions, and Judaism in particular because of the linkage to the period of obscurantism and oppression in history. Secular anti-Semitism highlights the assumption that modern society has overcome religious dogmas, the third major source of anti-Semitism in the Czech environment is inspired by biologically oriented theories that emphasize the differences between the nations, the races, and the civilizations. These views are promoted especially by the right-wing neo-Nazi groups. In this perspective, the Jews are usually categorized as the inferior race (Messadié, 2000, p. 296-303). The fourth source of anti-Semitism can be labelled as the economic reasons for hatred. These arguments are typical mainly for left-wing anti-Semites. They believe that the inequalities in the world are caused by the Jews who own most of the world wealth, and thus rule the world politics (Mikulášek, 2000, p. 17).

Today anti-Semitism in the Czech Republic is mainly associated with the marginal groups in the society, especially with the extreme right-wing and the extreme left-wing organizations. Due to the presence of the Muslim community in the Czech Republic the radical Muslims can be also seen as a 
potential threat to the Jewish community in the future. What is considered as a dangerous phenomenon is the growing support of radical Islam not only by the individuals but also by the official organizations (e.g. invitation for a controversial scholar Heitham al-Haddad by the Muslim Community in Prague). This argument is usually based on the comparison with the situation in the other European countries such as France where the individuals who identify themselves with Islam publicly have been responsible for the most serious anti-Semitic incidents in last few years (Taterová, 2016, p. 26-27).

Traditionally, the right-wing extremists in the Czech Republic have a very hateful attitude towards the Jewish community. Nowadays, many of the right-wing extremists call for a struggle against the existing political regime. The anti-Semitic right-wing movement conspire that the government of the Czech Republic is commanded by the Zionist movement, and thus do not pursue the best interests of Czech nation. As a concrete example, we can name the attacks by the neo-Nazi group White Justice on the former Czech Prime Minister Jan Fischer (in office 2009-2010). Jan Fischer who does not conceal his Jewish origins has been together with his family a long term target of the extremists. The campaign escalated in 2012 due to Fischer's candidature for Czech president (Židovská obec v Praze, 2012). However the political power of these groups is rather marginal, and concurrently their influence on the major society is not very significant. On the contrary, the leftist radicals express only indirect criticism of Jews. The main source of antagonism against the Jewish nation reflects the events of Arab-Israeli conflict, especially the rejection of Israeli foreign policy.

The following graphs based on annual reports on anti-Semitism in the Czech Republic in 2004 - 2014 show the trends in the number of anti-Semitic incidents, and the nature of anti-Semitic incidents.

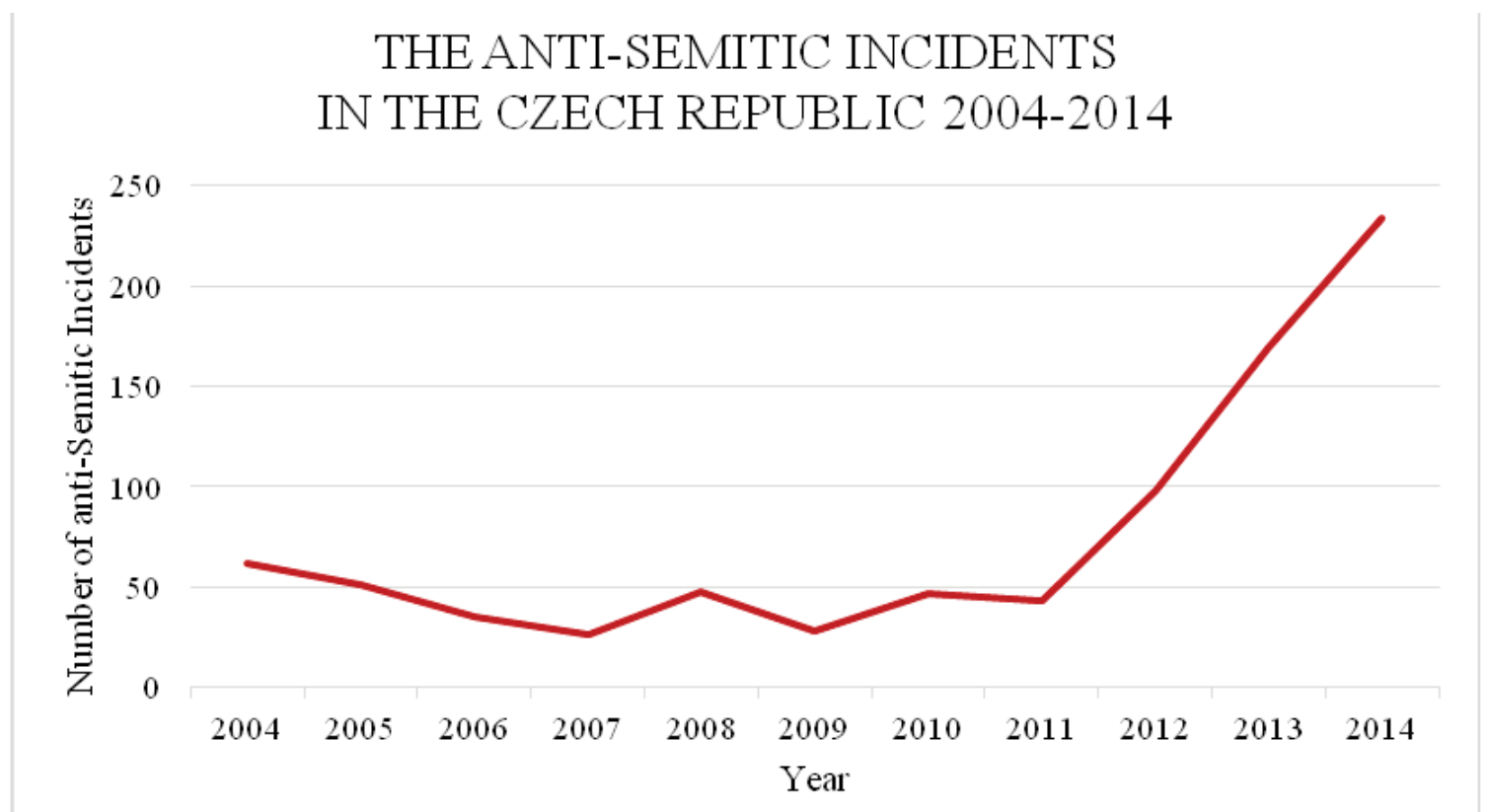

Graph 1. The anti-Semitic incidents in the Czech Republic 2004-2014.

Source: Authors' own work based on Annual reports on antisemitism in the Czech Republic 2004-2014. 


\section{TRENDS IN THE FORMS OF ANTI-SEMITISM IN THE CZECH REPUBLIC 2004-2014}

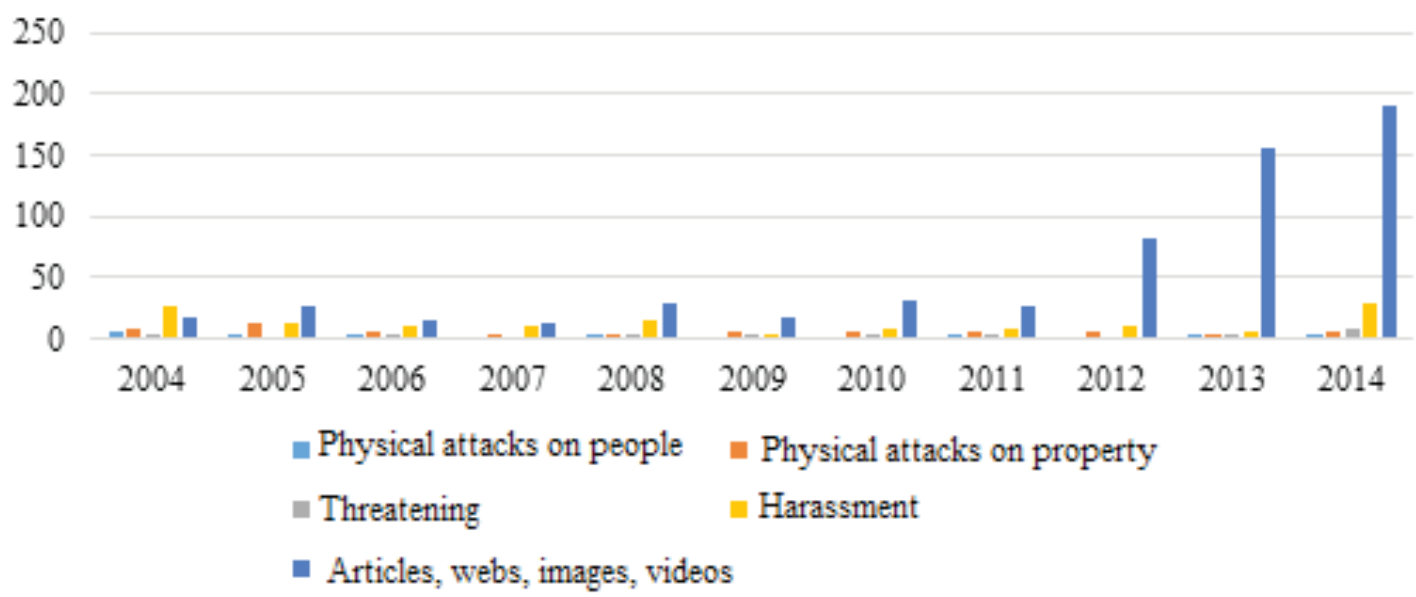

Graph 2. Trends in the forms of anti-Semitism in the Czech Republic 2004-2014.

Source: Authors' own work based on Annual reports on antisemitism in the Czech Republic 2004-2014.

Based on the graph no. 1 we can conclude that in the first decade of the $21^{\text {st }}$ century anti-Semitism in the Czech Republic was at a very low level and did not show any significant change. A considerable increase came in 2012 when the number of anti-Semitic incidents more than doubled. This trend continued in subsequent years when we can observe so far the highest number of anti-Semitic incidents. It is obvious that the physical attacks on Jews in the Czech Republic are almost absent. The low numbers are also typical for harassment and threatening behaviour. Despite the increase of anti-Semitic incidents in 2014, we can assume that Czech Jewish community was not exposed to a significant security risk. However, what can be seen as alarming is the rapid increase in anti-Semitic articles, videos, and images on Internet. In 2014, the anti-Semitic incidents in this category were more than twenty times higher in comparison to the beginning of the period.

We can assume that the trends in anti-Semitism in 2004-2007 were of a decreasing nature. The typical incidents were the attacks on Jewish property as well as harassment on the anti-Semitic base. In most of the cases, the offenders were predominantly right-wing radicals, and neo-Nazis who see the Jews as the long-term target. The typical targets of the anti-Semitic incidents included Jewish cemeteries, synagogues, monuments, and the other objects related to Judaism or Jewish history. The anti-Semitic Internet articles often denied the events of Holocaust, and also presented the conspiracy theories of Jewish world domination. The increase of these articles could be related to the ongoing trial of the revisionist Ernst Zündel (CBC News, 2007). In response to the situation in the Middle East where the bloody clashes between Israel and the Palestinians escalated in late 2004 (known as Second intifada) a wave of 
criticism raised in the Czech Republic. E.g. there was a demonstration held in Wenceslas Square in Prague to support the Palestinians in 2004.

A similar reaction appeared in 2006 in response to the armed conflict between Israel and Hezbollah. The Federation of Jewish Communities and the Jewish Community in Brno received the anonymous e-mails blaming the Jewish Community for unleashing the conflict, bombing the civilian targets, and the inability of Jews to lead the individual fight. In August 2006, several Czech Jewish organizations and the Israeli embassy in Prague received the letter from the neo-Nazi organization National Resistance. This letter was a copy of an application addressed to the president Vaclav Klaus - the authors asked for a permission to serve in Iranian army to fight against the Zionists and the State of Israel (Raxen, 2006). The development in 2008-2011 followed the previous trends in anti-Semitism in the Czech Republic. At the beginning of this period, however, there was the increase of anti-Semitic articles that appeared primarily in connection with the military operation Cast Lead launched by Israel in December 2008. In 2010, the number of anti-Semitic articles increased due to the clash of Israeli army and a Turkish fleet that was operating close to the coastline of the Gaza Strip (Židovská obec v Praze, 2011).

In 2012 we can observe more than a double increase of anti-Semitic articles in the Czech Republic. Obviously, such a significant increase was in connection to the presidential candidacy of Jan Fischer, the escalation of the Arab-Israeli conflict, and last but not least the strong pro-Israeli orientation of contemporary Czech government. Another reason was the new strategy of the right-wing extremists called "from the field to the internet". As a result, there were less public demonstrations but the extremists became more active on the Internet. The major society reflected the issue of the restitutions of property to the churches, including the Jewish communities - in general, the Church Property Restitution Bill was criticised heavily. This law became the impetus for hate speech against the churches, and also against the Jewish community. The increase of anti-Semitic articles came mainly in March 2012 as the situation in the Middle East escalated dangerously in connection with the development of Iran's nuclear program. Israeli Prime Minister Binyamin Netanyahu claimed that Israel was determined to strike on Iran if necessary. Another escalation came during the discussion in United Nations General Assembly about a status of Palestine as a non-member observer state. The Czech Republic was one of 8 countries in the world that denied this resolution. Subsequently Netanyahu visited Prague for the second time in 2012 to thank personally Czech Prime Minister Petr Nečas for the support in the United Nations (Židovská obec v Praze, 2012).

The trend of anti-Semitic manifestations in the cyberspace has continued till today. As for the situation in the Middle East, we can observe especially the reactions of both extreme left-wing and extreme right-wing radicals to the war in Syria, and the collapse of peace talks between Israel and the Palestinians. The main argument of right-wing and left-wing radicals was based primarily on blaming Israeli government for the political and economic pro- 
blem of the Czech Republic. These accusations had their origin in the conspiracy theories of Jewish world domination. Due to the similarity of topics of these groups, we can discuss whether there is a disappearance of differences between Czech right-wing and Czech left-wing groups regarding the attitudes towards the Jews (Židovská obec v Praze, 2013).

\section{CONCLUSION}

The information in the text above proved that anti-Semitism in the Czech Republic today is still a living phenomenon. Almost seventy years after the tragedy of the Holocaust when more than six million European Jews were killed, there are still groups of radicals who proclaim their antipathy, or in the worst case their open hatred against the Jewish people. Today most anti-Semitic manifestations take place on the Internet however the cases when someone has been prosecuted for spreading anti-Semitism are quite rare. As shown by the recent experience from the other countries of the world the social media can have a great power, and a great potential to influence the masses. Therefore, the risk of spreading anti-Semitism through the social media should not be underestimated, and Czech government should insist on the strict application of laws that prohibit any form of discrimination and the spread of extremist ideologies.

Every year, we can observe a few other types of anti-Semitic incidents outside the Internet, especially the attacks on property, threatening, and harassment. So far, there has not been any single attack on a human being but the experience from other European countries show that such a danger should not be underestimated. Anti-Semitism in the Czech Republic comes from both the right and the left of the political spectrum -the different types of the arguments are used in order to justify the hatred for Jews. While the particular emphasis on nationalism and highlighting differences between Jews and the major society is typical for the right-wing radicals, the left-wing radicals emphasize especially the economic aspects. In their view, the Jews are responsible for global capitalism and thus the inequality in the world. Although the rate of anti-Semitism in the Czech Republic in recent years has increased considerably, we can state that the conditions for the life of the Jewish community in the Czech territory are still very favourable, and thus Czech Republic can be seen as one of the safest countries in Europe for the Jews.

\section{REFERENCES}

[1] CBC News (2007). Ernst Zündel sentenced to 5 years for Holocaust denial. Retrieved from http:/ / www.cbc.ca/news/world/ernst-zundel-sentenced-to-5-years-for-holocaustdenial-1.659372.

[2] Čeněk, J., Smolík, J., \& Vykoukalová, Z. (2016). Interkulturní psychologie: Vybrané kapitoly [Intercultural Psychology: Selected Issues]. Prague: Grada.

[3] Český statistický úřad [Czech Statistical Bureau] (2011). Obyvatelstvo podle náboženské víry: Výsledky sčítáni lidu 2011 [The Population according to religion: Census Report 2011]. 
Retrieved from http://vdb.czso.cz/sldbvo/\#!stranka=podletematu\&tu=30562\&th=\&vseuz $\mathrm{emi}=$ null \&v$=\& \mathrm{vo}=$ null\&void $=$.

[4] Danics, S., \& Kamín, T. (2005). Extremismus, rasismus a antisemitismus [Extremism, racism, and anti-Semitism]. Prague: Policejní akademie ČR.

[5] Federace židovských obcív ČR [Federation of Jewish Communities in the Czech Republic] (2010). FŽO - Výroční zpráva za rok 2009: Výroční zpráva o antisemitismu v ČR 2009 [FJC - Annual Report 2009: Annual Report on anti-Semitism in the Czech Republic in 2009]. Retrieved from http://www.fzo.cz/wp-content/uploads/vyrocni-zprava-fzo-2009.pdf.

[6] Federace židovských obcí $v \check{C} R$ [Federation of Jewish Communities in the Czech Republic] (2005). Zpráva o projevech antisemitismu: Česká republika 2004 [Report on anti-Semitic Incidents: Czech Republic 2004]. Retrieved from http://www.fzo.cz/wpcontent/uploads/zprava-oprojevech-antisemitismu-cr-2004.pdf.

[7] Frankl, M., \& Jenšovská, J. (2013). Naši nebo cizí? Židév českém 20. století [Ours of Foreign? Jews in Czech 20 ${ }^{\text {th }}$ century]. Prague: Źidovské muzeum v Praze - Institut Terezínské Iniciativy

[8] Federerace židovských obcí v ČR [Federation of Jewish Communities in the Czech Republic] (2010). Statistika [Statistics]. Retrieved from http://www.fzo.cz/o-nas/statistika.

[9] Israel Ministry of Foreign Affairs (2013). Law of Return 5710-1950. Retrieved from http:/ / www. mfa.gov.il/mfa/mfa-archive/1950-1959/pages/law\%20of\%20return\%205710-1950.aspx.

[10] Kaplan, K. (1992). Zpráva o zavraždění generálniho tajemnika [Report on the Murder of the General Secretary]. Praha: Mladá fronta.

[11] Krejčová, H., \& Hyndráková, A. (1995). Postoj Čechů k židům. Z politického zpravodajství okupační správy a protektorátního tisku v letech 1939 - 1941 [The Czech Attitude towards Jews: From the Political Reports of the Occupation Administration and from the Protectorate Press, 1939-41]. Soudobé dějiny, 2 (4), 578-605.

[12] Messadié, G. (2000). Obecné dějiny antisemitismu: od starověku po dvacáté století [General History of anti-Semitism: From Antiquity to 20th Century]. Prague: Práh.

[13] Mikulášek, A. (2000). Antisemitismus v české literatuře 19. a 20. století [Anti-Semitism in Czech Literature in $19^{\text {th }}$ and $20^{\text {th }}$ Century]. Prague: Votobia.

[14] Raxen, (2007). Zpráva o stavu rasismu, xenofobie a antisemitismu v České republice v roce 2006 [The Report on Racism, Xenophobia, and anti-Semitism in the Czech Republic in 2006]. Retrieved from http://www.epolis.cz/download/pdf/materials_79_1.pdf.

[15] Ströbinger, R. (1991). Vražda generálního tajemníka : poslední Stalinův exemplární proces, soud s Rudolfem Slánským [The Murder of the General Secretary: Last Stalin's Exemplary Process, the Trial of Rudolf Slansky]. Brno: Petrov.

[16] Taterová, E. (2016). Vzestup antisemitismu ve Francii po roce 2000 [The Rise of Anti-Semitism in France since 2000]. Geografické rozhledy, 25 (3), 26-27.

[17] The Virtual Jewish Library (2014). The Jewish Population of the World. Retrieved from http:// www.jewishvirtuallibrary.org/jsource/Judaism/jewpop.html.

[18] Zídek, P., \& Sieber, K (2009). Ceskoslovensko a Blizký východ v letech 1948-1989 [Czechoslovakia and the Middle East in 1948-1989]. Praha: Ústav mezinárodních vztahů

[19] Židovská obec v Praze [Jewish Community in Prague] (2011). Výroční zpráva o projevech antisemitismu $v$ České republice za rok 2011 [Annual Report on anti-Semitic Incidents in the Czech Republic in 2011]. Retrieved from http://kehilaprag.cz/index.php?option=com_ docman\&task $=$ doc_view\&gid $=547 \& I t e m i d=211 \& l a n g=$ cs.

[20] Židovská obec v Praze [Jewish Community in Prague] (2012). Výroční zpráva o projevech antisemitismu $v$ České republice za rok 2011 [Annual Report on anti-Semitic Incidents in the Czech Republic in 2011]. Retrieved from http://www.kehilaprag.cz/index. php?option=com_docman\&task=doc_view\&gid=264\&Itemid=276\&lang=cs.

[21] Židovská obec v Praze [Jewish Community in Prague] (2013). Výroční zpráva o projevech antisemitismu v České republice za rok 2012 [Annual Report on anti-Semitic Incidents in the Czech Republic in 2012]. Retrieved from http://www.kehilaprag.cz/index.php?option=com_ docman\&task=doc_view\&gid $=408$ \&Itemid $=276 \& l a n g=c s$. 